\title{
KRIKŠČIONIŠKOS KILMĖS ASMENVARDŽIAI LIETUVOJE SENIAUSIOJE 1599-1621 M. JONIŠKIO PARAPIJOS KRIKŠTO METRIKŲ KNYGOJE
}

\author{
Alma RAGAUSKAITÉ \\ Lietuviu kalbos institutas
}

\section{Ivadas}

Joniškio parapijos istoriniai antroponimai kilmès aspektu jau pradèti tirti. Ypač svarbus šios parapijos seniausios 1599-1621 m. krikšto metrikų knygos tyrimų kontekstas. Pirmiausia buvo pateikta būdingesnių aptariamos knygos tekstų pavyzdžių (ịvairių krikšto įrašų formulių), kuriuose užfiksuota lietuviškos kilmès vyrų asmenvardžių (Garliauskas 1998: 152-153; 2004: 22-24). Išnagrinejjus to paties bažnytinio šaltinio 186 Joniškio miesto gyventoju antroponimus, paaiškejjo, jog tarp krikščioniškos kilmės asmenvardžių daugiausia atsiradusiu iš trumpųiu krikšto vardų lyčių. Palyginus Joniškio ir parapijos kaimų vardynus, pastebèta, kad miestiečiu antroponimai kilmès požiūriu skiriasi nuo valstiečių. Pastarųjų vardyne buvo dažnesni lietuvių senieji dvikamieniai asmenvardžiai (Ragauskaite 2004: 16-17). Išanalizavus kalbamosios parapijos kaimų gyventojų dvinarius įvardijimus, nustatyta, jog 187 antrieji antroponimai yra lietuviškos kilmès. Iš aptartų 187 lietuviškos kilmès asmenvardžių buvo rekonstruota 112 skirtingų antroponimų lyčių. Tarp jų lietuvių senųjų dvikamienių asmenvardžių - 36 (32\% visų atkurtų), dvikamienių antroponimų trumpinių bei jų priesaginių vedinių - 19 (17\%), pravardinès kilmès asmenvardžiu - 57 (51\%). Sugretinus 112 atkurtų antroponimų formų su dabartinemis lietuvių pavardèmis, prieita prie išvados, jog $46(41 \%)$ funkcionuoja ir šiandien. Didesnè dalis, t. y. 62 (55\% visu rekonstruotu), turi tos pačios kilmès, tik skirtingos darybos atitikmenis tarp dabartinių pavardžių. Likusiųų 4 (4 \%) nėra šių dienų vardyne (Ragauskaitė 2019a: 162). Atkreipus demesị i XVI a. pabaigos - XVII a. pradžios Joniškio parapijos vyrų antroponimų etimologinius ypatumus, tolesnis kaimų gyventojų istorinès antroponimijos tyrimas yra svarbus ir tęstinas.

Antroponimine medžiaga straipsniui surinkta iš senosios 1599-1621 m. Joniškio parapijos krikšto metrikų knygos. Šio bažnytinio šaltinio pavadinimas pateiktas lotynų kalba „Liber Baptisatoru(m) ${ }^{1} \|$ Ecc(lesi)æ Parochialis Jani= ||scensis ab Anno 1599. - || usq(ue) ad An(n)um || 1621. -“. Priešlapyje

1 Rankraštyje užfiksuotos abreviatūros pildytos. Prierašas nurodytas skliaustuose. 
nurodyta dar viena lotyniška antraštė „CATA: || LOGVS. || BAPTISATO: \| RVM. EC: || CLESIÆ. || IANI: || SCEN: || SIS“. Aptariama rankraštinė knyga rašyta lotynų ir lenkų kalbomis (Garliauskas 1998: 139; 2004: 21-22; Ragauskaite 1999: 155; 2005: 66-67; 2015: 74; 2019a: 154). Palyginus braižą matyti, kad šią knygą raše bent keli asmenys. Nè vienas iš jų neįrašè savo pavardès. Krikšto registracijos formulès buvo įvairios (ilgesnès ir trumpesnės). Keliolikoje lapų nerašomi oikonimai, dalyje knygos įrašų tekstas buvo trumpinamas (rašomi tik asmenų vardai, nerašomi antrieji ar tretieji įvardijimo nariai). Kai kuriais atvejais nurodytas Šiaulių valsčiaus (nuo 1616 m. faktiškai veikusios Šiaulių ekonomijos) vaitas, kurio vaitystëje yra kaimas (Žilys 2012: 127).

Šio straipsnio tikslas - apibūdinti 1599-1621 m. Joniškio parapijos kaimų gyventojų užrašymo situaciją, išsamiai aptarti atrinktus 556 krikščioniškos kilmès asmenvardžius (antruosius dvinario įvardijimo modelio narius) darybos aspektu.

Šio straipsnio uždaviniai: 1) trumpai aptarti vardus (pirmuosius dvinarių ịvardijimų narius); 2) nurodyti produktyviausias antrųjų asmenvardžių priesagas; 3) rekonstruoti antroponimų formas, kurios šaltinyje turi užfiksuotus lietuviškus darybos formantus, ir palyginti jas su dabartinėmis lietuvių pavardèmis; 4) nustatyti, kurie analizuojami istoriniai asmenvardžiai nebefunkcionuoja dabartiniame vardyne.

Aptariant XVI a. pabaigos - XVII a. pradžios Joniškio parapijos istorinès antroponimijos duomenis, taikomi šie pagrindiniai tyrimo metodai: aprašomasis ir lyginamasis (Ragauskaitė 2005: 31; 2019b: 179). Reikès nustatyti dažniausias asmenvardžiu priesagas, apibūdinti patronimų ir nepatroniminès kilmès antroponimų grupių kiekybinį santykį.

\section{Asmenų vardai}

Svarbu aiškiai apibrèžti, kurie bažnytiniame šaltinyje užrašyti antroponimai priskirtini Joniškio parapijos kaimų gyventojams (Ragauskaitė 2019a: 155). Jų asmenvardžius atskirti padeda kaimų nuorodos lotynų ir lenkų kalbomis, pvz.: 1617 Matis Bohdanajtis <...> de villa Darginy JNŠ 1982; 1601 Pagi S3łostikiow <...> Martini Czepaitis JNŠ 22v; 1619 S(iola) Wekiunow <...> Philip Grigaitis JNŠ 237; 1620 Mikolaÿ Ionaytis <...> Siola Aleknayciow JNŠ 253; 1617 Iakub Iurgajtis de uilla Kiwile JNŠ 206v;

2 Visi straipsnyje pateikti asmenų įvardijimai yra metrikuoti. Prie kiekvieno jų pažymèti metai, kuriais įvardijimas buvo užfiksuotas, istorijos šaltinio santrumpa ir lapo numeris. 
1601 Pagi Proczunow <...> Lucæ Jesaỳtis JNŠ 21v; 1621 S(iola) Medginiow Grig Maciehewicz JNŠ 265; 1619 Thomaß Marczynaitis <...> S(iola) Bilziow JNŠ 235v; 1620 Casper Mikalaitis <...> Siola Norunow JNŠ 252v; 1620 Gregor Petraitis <...> Siola Krampiow JNŠ 252v; 1620 Pawel Stanisłowaitis <...> S(ioła) Powilaÿciow JNŠ 253; 1617 Pawel Tomaßewicz de uilla Lidayki JNŠ 200; 1620 S(iola) Butniunow < ...> Ian Waićiekaitif JNŠ 251v; 1606 S(ioło) Normanciow <...> Maciulis Wenskaitis JNŠ 86v; 1620 Sioła Trumpaiciow <...> Maczë̈ Woyciekowicz JNŠ 251v.

Parapijos kaimuose gyveno krikštijamų kūdikių tėvai, krikšto tėvai, pvz.: 1601 Pagi Rukayciow <...> Patr(ini) Gregorius Bartkuns JNŠ 21; 1601 Pagi Jenkunu <...> Patr(ini) Stanislaus Endrufzaitis JNŠ 24; 1601 Pagi Jakifzkiu <...> Patr(ini) Geniulis Endrufzkaỳtis JNŠ 21; 1601 Pagi Stagia <...> Patr(ini) Simon Gricaitis JNŠ 22; 1601 Patr(ini) Jacobus Jekaytis Pagi Mikalajciunow JNŠ 18v; 1601 Pagi Barifiu <...> Patr(ini) Staś Jenaitis JNŠ 18v; 1606 Sioła Jonaiciow R(odzice) Jerzi Martinaitis JNŠ 86v; 1620 K(um) Stanisław Mikolaitis <...> Sioła Kiepałow JNŠ 253; 1618 Patr(ini) Gregorzy Pietraßajtis de eadem uilla JNŠ 219v; 1617 Par(entes) Iakob Romanaytis <...> de uilla JNŠ 206v; 1621 S(iola) Melniow R(odzic) Simon Woiciechewicz JNŠ 264v.

Pirmieji šiu dvinarių ịvardijimų nariai dažniausiai yra tradiciniai krikščioniški vardai, pvz.: 1601 Ambrosius JNŠ 30v³; 1621 Ambrozei JNŠ 262v(2) 1619 Ambroziey் JNŠ 236v; 1619 Ambroźiey் JNŠ 237v; 1620 Ambrozië̈ JNŠ 246; 1620 Ambroziey JNŠ 249; 1620 Ambrozieÿ JNŠ 257 - plg. db. v. Ambraziẽjus (LVKŽ 73); 1601 Andreæ gen. sg. JNŠ 18; 1617 Andreius JNŠ 199; 1617 Andrzey JNŠ 207; 1617 Andrzey JNŠ 198; 1617 Andrzej JNŠ 202v; 1620 Iendrzei JNŠ 248; 1618 Iendrzey JNŠ 221v; 1609 Jendrzë̈ JNŠ 109v; 1620 Jęndrzey JNŠ 259; 1616 jendrzej JNŠ $191-$ plg. db. v. Andriẽjus (LVKŽ 74); 1621 Anton JNŠ 265v; 1617 Antonius JNŠ 208v - plg. db. v. Antãnas (LVKŽ 76); 1621 Augustin JNŠ 262; 1620 Auguftin JNŠ 254v; 1601 Auguftini gen. sg. JNŠ 20; 1601 Augustin(us) JNŠ 22; 1601 Auguftinus JNŠ 22v - plg. db. v. Augustinas (LVKŽ 85); 1609 Baltromieỳ JNŠ 109; 1609 Battromieÿ JNŠ 109; 1616 Battromiej JNŠ 192v; 1601 Bartholomęus JNŠ 29; 1601 Bartholomæus JNŠ 28; 1618 Bartlomiey் JNŠ 222; 1617 Bartlomiej

3 Vardai ir antrieji antroponimai suregistruoti pagal jų formų abėcèlę. Nurodomos skirtingos asmenvardžių užrašymo lytys, greta nurodant tik po vieną lapą, kuriame ši forma buvo paminėta. Išsamus antroponimų paplitimo registras labai išplèstų šio straipsnio apimtį. Perteikiant asmenvardžius, stengiamasi išsaugoti originalias, bažnytinejje metrikų knygoje fiksuotas lytis.

4 Skliaustuose surašyti numeriai nurodo asmenų, turinčių vienodą vardą, skaičių tame pačiame bažnytinio dokumento lape. 
JNŠ 198v - plg. db. v. Baltramiẽjus (LVKŽ 89); 1617 Casper JNŠ 198; 1617 Caspros JNŠ 204v; 1618 Kasper JNŠ 215 - plg. db. v. Kãsparas (LVKŽ 222); 1601 Chriftophorus JNŠ $25 \mathrm{v}-$ plg. db. v. Kristofòras, Kristòforas (LVKŽ 237); 1621 Elexander JNŠ 265 - plg. db. v. Aleksándras (LVKŽ 65); 1618 Floryan JNŠ 214 - plg. db. v. Florijõnas (LVKŽ 158); 1601 Gaspari gen. sg. JNŠ 20v; 1601 Gasparus JNŠ 18v - plg. db. v. Gãsparas (LVKŽ 164); 1601 Georgius JNŠ 19v; 1617 Iurgis JNŠ 207v; 1601 Jurgis JNŠ 22 - plg. db. v. Jùrgis (LVKŽ 215); 1618 Grygalis JNŠ 220; 1617 Grygalus JNŠ 199v; 1617 Grygalus JNŠ 202v; 1618 Grýgalus JNŠ 218v - plg. db. v. Grigãlius (LVKŽ 188); 1617 Iacobus JNŠ 206v; 1621 Iacub JNŠ 260v; 1617 Iakob JNŠ 206v; 1617 Iakob(us) JNŠ 199; 1617 Iakub JNŠ 243; 1601 Jacobi gen. sg. JNŠ 20v; 1601 Jacobo JNŠ 27; 1601 Jacobus JNŠ 18v; 1601 Jacob(us) JNŠ 20v; 1620 Jaćub JNŠ 253v; 1617 Jakob JNŠ 201v; 1609 Jakub JNŠ 111v — plg. db. v. Jokũ bas (LVKŽ 207); 1617 Ian JNŠ 200; 1617 Ianos JNŠ 197(2); 1609 Jan JNŠ 109; 1601 Joannes JNŠ 21v; 1601 Joannis JNŠ 20v - plg. db. v. Jõnas (LVKŽ 208); 1620 Ieronim JNŠ 251v - plg. db. v. Jerònimas (LVKŽ 204); 1620 Iozeph JNŠ 248; 1601 Josephus JNŠ 18; 1615 jozephus JNŠ 173v plg. db. v. Juõzapas (LVKŽ 214); 1601 Laurentius JNŠ 20; 1616 Laurentj JNŠ 191; 1619 Laurin JNŠ 242; 1616 Lawrÿn JNŠ 192v; 1617 Lawrÿnas JNŠ 199; 1620 Wauwriniec JNŠ 248; 1620 Wawriniec JNŠ 251v - plg. db. v. Laurỹnas (LVKŽ 242); 1601 Lucas JNŠ 28v; 1601 Lucæ gen. sg. JNŠ 18v; 1620 Lukas JNŠ 249 - plg. db. v. Lùkas (LVKŽ 255); 1621 Maciei JNŠ 261v; 1617 Maciey JNŠ 204; 1618 Maciey JNŠ 211v(2); 1620 Maciey JNŠ 257v; 1617 Moteius JNŠ 197v - plg. db. v. Motiẽjus (LVKŽ 279); 1621 Marcin JNŠ 261; 1620 Marczyn JNŠ 247; 1617 Martin JNŠ 206; 1601 Martini gen. sg. JNŠ 22v - plg. db. v. Martỹnas (LVKŽ 264); 1601 Marc(us) JNŠ 18v; 1618 Markus JNŠ 209; 1618 Markuf JNŠ 210v; 1601 Mork(us) JNŠ 28 - plg. db. v. Mõrkus (LVKŽ 279); 1618 Michał JNŠ 210v - plg. db. v. Mýkolas (LVKŽ 270); 1616 Mikolai JNŠ 191; 1617 Mikolay JNŠ 199; 1618 Mikolay JNŠ 210; 1620 Mikolä̈ JNŠ 251; 1617 Mikolaj JNŠ 198; 1601 Nicolai JNŠ 20; 1601 Nicolaus JNŠ 19v - plg. db. v. Mikalõjus (LVKŽ 270); 1617 Patroś JNŠ 199; 1601 Petri gen. sg. JNŠ 20; 1601 Petrus JNŠ 19v; 1620 Piotr3 JNŠ 252 - plg. db. v. Pẽtras (LVKŽ 299); 1601 Pauli gen. sg. JNŠ 21v; 1601 Paulus JNŠ 19v; 1601 Paul(us) JNŠ 26 - plg. db. v. Paũlius (LVKŽ 298); 1609 Pawel JNŠ 112; 1617 Pawel JNŠ 200(2); 1617 Powilaf JNŠ 204v - plg. db. v. Póvilas (LVKŽ 301); 1619 Philip JNŠ 237 - plg. db. v. Pilỹpas (LVKŽ 300); 1601 Sebaftianus JNŠ 21; 1621 Sebestian JNŠ 264; 1620 Sebeftian JNŠ 251v - plg. db. v. Sebastijõnas (LVKŽ 325); 1601 Simon JNŠ 22; 1618 Symon JNŠ 213v - plg. db. v. Simonas (LVKŽ 329); 1601 Stanislaus 
JNŠ 21; 1618 Stanifłaus JNŠ 221; 1618 Stanislaw JNŠ 210; 1619 Stanisław JNŠ 233v; 1617 Stanifław JNŠ 203v; 1621 Stanisła(w) JNŠ 270v - plg. db. v. Stanislovas (LVKŽ 335); 1617 Stephan JNŠ 193; 1601 Stephanus JNŠ 18v - plg. db. pvd. Stẽponas (LVKŽ 336); 1601 Thomas JNŠ 20; 1601 Thomæ gen. sg. JNŠ 20v; 1616 Tomas JNŠ 193 - plg. db. v. Tòmas (LVKŽ 350); 1618 Tomaßus JNŠ 213; 1617 Tomasz JNŠ 200 - plg. db. v. Tamõšius (LVKŽ 341); 1620 Walentin JNŠ 248; 1620 Walentÿn JNŠ 256; 1601 Valentini gen. sg. JNŠ 20; 1601 Valentinus JNŠ $18 \mathrm{v}$ - plg. db. v. Valentinas (LVKŽ 363); 1620 Woiciech JNŠ 257; 1617 Woyciech JNŠ 207; 1618 Woyciechüs JNŠ 211; 1617 Wojtechüs JNŠ 197 - plg. db. v. Vaitiêkus (LVKŽ 361); 1616 Vrban JNŠ 192v; 1601 Vrbani gen. sg. JNŠ 20v; 1601 Vrbanus JNŠ 22; 1618 Vrban(us) JNŠ 214v - plg. db. v. Urbonas (LVKŽ 353); 1617 Zygmont JNŠ 207 - plg. db. v. Zìgmantas (LVKŽ 384).

Mažiau pastebėta kanoninių krikščioniškų vardų trumpinių, pvz.: 1621 Gabris JNŠ 266v - plg. db. v. Gabrỹs (LVKŽ 160) < Gabriēlius (LVKŽ 160); 1616 Grig JNŠ 192; 1617 Gryg JNŠ; 1620 Grigas JNŠ 253v; 1616 grigas JNŠ 193; 1617 Grygaf JNŠ 207v; 1617 Grygaś JNŠ 202v - plg. db. v. Grigas (LVKŽ 188) < Grigãlius (LVKŽ 188); 1621 Sim JNŠ 260 - plg. db. v. Sìmas < Sìmonas (LVKŽ 329); 1618 Staniuf JNŠ 210v - plg. db. v. Stãnius (LVKŽ 335) < Stanislovas (LVKŽ 335); 1618 Stasius JNŠ 210; 1617 Stäsius JNŠ 205; 1601 Stafius JNŠ 18 - plg. db. v. Stãsius (LVKŽ 335) < Stanislovas (LVKŽ 335); 1620 Walenti gen. sg. JNŠ 253v; 1617 Walenty JNŠ 202; 1616 Walenty JNŠ 193 - plg. db. v. Vãlentas, Valeñtas (LVKŽ 363).

Pasitaikè deminutyvinių krikštavardinių vardų formų, pvz.: 1617 Andrutis JNŠ 197 - plg. db. v. Añdrius (LVKŽ 75) < Andriẽjus (LVKŽ 74); 1620 Antul JNŠ 247 - plg. db. v. Ántas (LVKŽ 76) < Antãnas (LVKŽ 76); 1601 Jonelis JNŠ 26 - plg. db. v. Jõnas (LVKŽ 208); 1601 Jurgelis JNŠ $27 \mathrm{v}-$ plg. db. v. Jùrgis (LVKŽ 215); 1601 Mikucia gen. sg. JNŠ 22; 1618 Mikutys JNŠ 220; 1617 Mikutyf JNŠ 205v - plg. db. v. Mìkas (LVKŽ 270) < Mikalõjus (LVKŽ 270); 1621 Tamul JNŠ 259v - plg. db. v. Tòmas (LVKŽ 350).

Antrieji dvinarių ịvardijimų nariai - tai krikščioniškos kilmès asmenvardžiai su priesagomis arba be priesagų, kurie toliau analizuojami darybos aspektu.

\section{Antroponimų darybos tendencijos}

Lietuvių pavardes, kilusias iš populiariausių krikšto vardų lyčių (ilgųiu, lietuvių kalboje susidariusiu ar skolintų trumpinių, mažybinių bei kitokių priesagų vedinių) išsamiai yra aprašęs Aleksandras Vanagas (1974: 86-152; 
1977: 48-92; 1980: 52-95; 1982: 73-97; 1983: 73-103). Nemažą dali šios kilmès pavardžių išaiškino Zigmas Zinkevičius (1977a: 66-89; 2005: 16-43; 2007: 22-23; 2008: 343-484; 2010: 9-106). Daugiausia šio tipo pavardžių yra išanalizuota Lietuviu pavardžiu žodyno dvitomyje (Vilnius: Mokslas, 19851989). Nagrinejjant lietuvių pavardžiu formavimosi procesą, krikščioniškos kilmès asmenvardžius aptarė Vitalija Maciejauskienè (1991: 219; 222-223; 230-232; 233-236). Tarp nelietuviškos kilmės XVI-XVIII a. kauniečių antroponimų daugiausia buvo kilusių iš krikščioniškų vardų (XVI a. - 29 \%, XVII a. - 31 \%, XVIII a. - 32 \%) (Ragauskaite 2005: 119, 125, 133).

Aptariami 1599-1621 m. Joniškio parapijos kaimų gyventojų krikščioniškos kilmés asmenvardžiai suklasifikuoti ị dvi grupes: 1) antropinimai su lietuviškomis -aitis, -(i)onis, -(i)ūnas, -(i)uitis ir slaviškomis -evič, -ovič patroniminèmis priesagomis, su deminutyvinèmis priesagomis ir 2) asmenvardžiai be šių priesagų (dèl šios klasifikacijos dar žr. Maciejauskienè 1993: 40; Ragauskaitė 2018a: 104-106; 2019a: 182). Antroponimai yra rekonstruojami iš patronimų ir nepatroniminès kilmès asmenvardžių. Atkurtos antroponimų formos pažymimos rekonstrukcijos ženklu ir pateikiamos pagal abėcèlę. Šios formos lyginamos su dabartinėmis lietuvių pavardèmis. Kaip minèta, 1599-1621 m. Joniškio parapijos krikšto metrikų knygoje buvo užrašyti 556 kaimų gyventojų krikščioniškos kilmès asmenvardžiai. Prie pirmosios grupès priskirti 552 (99,28 \% visų antrųų antroponimų) asmenvardžiai. Jie pateikiami pagal priesagu produktyvumą:

-aitis (rašymas varijuoja: -aycis, -aitis, -aitif, -aitýs, -aytis, -áytis, -aytis, -aytis, -aÿtis, -ajtis, -atis) - 359 (64,55 \%) antroponimai: *Adom a it is : 1620 Adomaitis JNŠ 258v. Plg. db. pvd. Adomáitis (LPŽ I 65); *Andrekaitis : 1617 Andrekaytis JNŠ 206v. Plg. db. pvd. Andrekáitis (LPŽ I 99); *Andrukaitis: 1617 Andrukaytis JNŠ 207v; 1617 Andrukajtis JNŠ 198v. Plg. db. pvd. Andrukáitis (LPŽ I 103); *A ug ust i na it is : 1601 Auguftinaitis JNŠ 24v; 1617 Augustẏnajtis JNŠ 199. Plg. db. pvd. Augustináitis (LPŽ I 137); * Bagdo naiti s : 1621 Bagdonaitis JNŠ 271. Plg. db. pvd. Bagdonaitis (LPŽ I 153); * B a n a it i s : 1601 Banaitis JNŠ 25; 1601 Banaytis JNŠ 30v; 1617 Banajtis JNŠ 203v. Plg. db. pvd. Banáitis (LPŽ I 184); *B a ri s a it is : 1601 Barifaitis JNŠ 26. Plg. db. pvd. Barisáitis (LPŽ I 197); * B art ka it is : 1601 Bartkaitis JNŠ 25. Plg. db. pvd. Bartkáitis (LPŽ I 203); * B a r to š a it i s : 1618 Bartoßaytis JNŠ 219v. Plg. db. pvd. Bartošáitis (LPŽ I 205); * B e r no ta it i s : 1619 Bernotaitis JNŠ 234v. Plg. db. pvd. Bernotáitis (LPŽ I 240); *Č e p a i ti s : 1601 Czepaitis JNŠ 22v; 1620 czepaitis JNŠ 247; 1618 Czepaytis JNŠ 221v; 1618 czepaytis JNŠ 219. Plg. db. pvd. Čepáitis (LPŽ I 410); *Endru ša i t is : 1601 Endrufzaitis JNŠ 24. Plg. db. pvd. Endrušaitis (LPŽ I 577); * Endr u ška it i s : 
1601 Endrufzkaẏtis JNŠ 21. Plg. db. pvd. Endruškaitis (LPŽ I 577); * Grigai ti s : 1609 Grigaitis JNŠ 109; 1615 grigaitis JNŠ 174v; 1617 Grygajtis JNŠ 198v. Plg. db. pvd. Grigáitis (LPŽ I 710-711); *Grigalaiti s: 1620 Grigalaitis JNŠ 243; 1601 Gryggalaytis JNŠ 22; 1617 Grygałajtis JNŠ 202. Plg. db. pvd. Grigaláitis (LPŽ I 711); *Griškaitis: 1601 Grifzkaitis JNŠ 22. Plg. db. pvd. Griškáitis (LPŽ I 721); *Jakaitis: 1620 Iakaitis JNŠ 243; 1617 Jakaytis JNŠ 208. Plg. db. pvd. Jakáitis (LPŽ I 785); *Ja s a it i s : 1620 Iasaitis JNŠ 258. Plg. db. pvd. Jasáitis (LPŽ I 813); *Jo ca it is : 1621 Iocaitis JNŠ 264v. Plg. db. pvd. Jocáitis (LPŽ I 835); *Jok ūba it i s : 1621 Iacubaitis JNŠ 264v; 1620 Iakubaitis JNŠ 258; 1617 Iakübajtis JNŠ 198v; 1620 Iokubaÿtis JNŠ 255v; 1616 jocubaitis JNŠ 191v; 1616 jokubaitis JNŠ 192v. Plg. db. pvd. Jókūbaitis, Jokūbáitis (LPŽ I 839); *Jo na it is : 1621 Ianaitis JNŠ 260; 1617 Ianaytis JNŠ 205v; 1617 Ianaytiš JNŠ 204; 1617 Ianajtis JNŠ 197; 1620 Ionaitis JNŠ 241v; 1620 Ionaitỳs JNŠ 254; 1617 Ionaytis JNŠ 199; 1601 Jonaitis JNŠ 20; 1616 jonaitis JNŠ 193; 1618 Jonaytis JNŠ 213; 1601 Jonaytis JNŠ 20. Plg. db. pvd. Jonáitis (LPŽ I 841); *Jonkait is: 1601 Jonkaitis JNŠ 30. Plg. db. pvd. Jonkáitis (LPŽ I 843); *Jo n ulait is: 1620 Ianulaitis JNŠ 249v. Plg. db. pvd. Jonulaitis (LPŽ I 844); *Jo n u ša it is : 1621 Ianußaitis JNŠ 269; 1618 Ianußaytis JNŠ 210; 1617 Ianu்szaytis JNŠ 199; 1604 Jonußaitis JNŠ 48. Plg. db. pvd. Jõnušaitis, Jonušáitis (LPŽ I 844); *Juknaitis : 1618 Iuknaytis JNŠ 212. Plg. db. pvd. Juknáitis (LPŽ I 852); *Jurgaitis : 1620 Iurgaitis JNŠ 251v; 1617 Iurgaytis JNŠ 204v; 1617 Iurgajtis JNŠ 206v; 1601 Jurgaitis JNŠ 19v; 1615 jurgaitis JNŠ 174v; 1601 Jurgaytis JNŠ 22. Plg. db. pvd. Jùrgaitis, Jur̃gaitis, Jurgáitis, Jurgaitis (LPŽ I 866); *Jurkaitis : 1617 Iurkaycis JNŠ 208. Plg. db. pvd. Jurkáitis (LPŽ I 868-869); *Ju šk a it i s : 1620 Juskaitis JNŠ 259. Plg. db. pvd. Juškáitis (LPŽ I 874); *Ka s p a ra it i s : 1620 Casparaitif JNŠ 249v. Plg. db. pvd. Kãsparaitis, Kasparáitis, Kasparaitis (LPŽ I 940); * La u ry na it is : 1601 Laurinaýcia gen. sg. JNŠ 19v; 1621 Laurinaitis JNŠ 260(2); 1601 Laurinaytis JNŠ 18v; 1618 Lawrynaytis JNŠ 213v; 1618 Lawrynaytis JNŠ 209v; 1617 Lawrynnaytis JNŠ 205; 1617 Lawrynajtis JNŠ 203; 1618 Lawrynajtis JNŠ 213; 1618 Lawrynatis JNŠ 221. Plg. db. pvd. Laurynáitis (LPŽ II 35); *Lukošaitis: 1618 Lukaßaytis JNŠ 212; 1601 Lukoßaitis JNŠ 25; 1621 Lukoszaitis JNŠ 264v; 1601 Lukoszaỳtis JNŠ 28v. Plg. db. pvd. Lukošáitis (LPŽ II 114); *Ma cait is: 1601 Macaitis JNŠ 22; 1602 Macaẏtis JNŠ 39; 1618 macaytis JNŠ 222; 1617 Matfaytis JNŠ 206; 1618 matfaỳtis JNŠ 218; 1617 Matsajtis JNŠ 198. Plg. db. pvd. Macáitis (LPŽ II 30); *Martynaitis : 1601 Martinaýcia gen. sg. JNŠ 22; 1601 Martinaitis JNŠ 25; 1617 Martinaytis JNŠ 200; 1617 martinaytis JNŠ 200v; 1617 Martinajtis JNŠ 202v; 1617 Martynajtis JNŠ 203v; 1617 Martjnajtis JNŠ 196v. 
Plg. db. pvd. Martynáitis (LPŽ II 167); * Mart in ka it i s : 1601 Martinkaitis JNŠ 24v. Plg. db. pvd. Martinkáitis (LPŽ II 168); *Mata i t is: 1618 matáytis JNŠ 216. Plg. db. pvd. Matáitis (LPŽ II 177); *Mat u la i ti s : 1616 Matułaitis JNŠ 191v. Plg. db. pvd. Matuláitis (LPŽ II 183); ${ }^{*}$ Mi ka it i s : 1601 Mikaycia gen. sg. JNŠ 20v; 1601 Mikaýcia gen. sg. JNŠ 20v; 1616 Mikaitis JNŠ 192v; 1601 Mikaỳtis JNŠ 27; 1619 Mikaÿtis JNŠ 231v; 1601 Mikajtis JNŠ 28. Plg. db. pvd. Mikáitis (LPŽ II 225); *Mi k el a i t is : 1601 Mikielaitis JNŠ 30. Plg. db. pvd. Mikelaitis, Mikeláitis, Mikelaitis (LPŽ II 228); *My ko la i t is : 1620 Mikolaitis JNŠ 253. Plg. db. pvd. Mykoláitis (LPŽ II 231); *Mikutaitis: 1601 Mikutaitis JNŠ 22; 1617 Mikutajtis JNŠ 198v. Plg. db. pvd. Mìkutaitis, Mikutáitis (LPŽ II 236); *Motiejaitis : 1601 Moteiaytis JNŠ 27. Plg. db. pvd. Motiejáitis (LPŽ II 274); *Mo ti e k a it is : 1601 Motekaitis JNŠ 25v. Plg. db. pvd. Motiekáitis (LPŽ II 274); * Pa tra i ti s : 1617 Patraytis JNŠ 200v. Plg. db. pvd. Patráitis (LPŽ II 406); *Pa u la it i s: 1617 Pawlaytis JNŠ 207v. Plg. db. pvd. Pauláitis (LPŽ II 408); *Peči ulait is: 1616 pećiulaitis JNŠ $192 \mathrm{v}$. Plg. db. pvd. Pèčiulaitis, Pečiuláitis, Pečiulaitis (LPŽ II 420); *Petraitis: 1601 Petraitis JNŠ 21; 1609 petraitis JNŠ 111; 1601 Petraytis JNŠ 19v; 1601 Petraỳtis JNŠ 19v; 1620 Petraÿtis JNŠ 256; 1618 Pietraytis JNŠ 213v. Plg. db. pvd. Petráitis (LPŽ II 437); *Petrikait is: 1620 Petricaitis JNŠ 251; 1601 Petrikaitis JNŠ 25v; 1601 Petrikaytis JNŠ 18v; 1617 Pietrykaytis JNŠ 205. Plg. db. pvd. Petrikáitis (LPŽ II 440); *Pet ri la i t i s : 1601 Petrilaitis JNŠ 30v; 1604 Petrilaÿtis JNŠ 48v. Plg. db. pvd. Petrilaitis (LPŽ II 441); * Pet ru š a it is : 1618 Pietrußaytis JNŠ 222. Plg. db. pvd. Petrušáitis (LPŽ II 444); *Povila it i s: 1604 Powełaytis JNŠ 48v; 1619 Powilaitis JNŠ 235; 1616 powilaitis JNŠ 191; 1609 Powilaytis JNŠ 109v; 1601 Powilaytis JNŠ 26v; 1621 Powẏlaitis JNŠ 261; 1617 Powilajtis JNŠ 202v. Plg. db. pvd. Póvilaitis, Poviláitis, Povilaitis (LPŽ II 496, 497); *S a ba i t is : 1620 Sabaitis JNŠ 258. Plg. db. pvd. Sabáitis (LPŽ II 651); *Stanaitis: 1601 Stanaitis JNŠ 24; 1621 stanaitis JNŠ 270v; 1619 stanaitif JNŠ 237v; 1601 Stanaytis JNŠ 19v; 1601 Stanaytis JNŠ 30; 1617 Stanajtis JNŠ 197. Plg. db. pvd. Stanáitis (LPŽ II 798); *S ta n i slov a it i s: 1620 Stanislowaitis JNŠ 253; 1621 Stanslowaitis JNŠ 263v. Plg. db. pvd. Stanislováitis (LPŽ II 801); *S ta n i u la i t i s : 1609 Staniulaitis JNŠ 109; 1601 Staniułaỳtis JNŠ 21v. Plg. db. pvd. Staniuláitis (LPŽ II 802); *Sta n ka it i s: 1601 Stankaytis JNŠ 18v. Plg. db. pvd. Stankáitis (LPŽ II 802); *S ta s a it i s : 1620 Stasaitis JNŠ 256; 1601 Stafaitis JNŠ 29v. Plg. db. pvd. Stasáitis (LPŽ II 807); *Šimait is : 1620 Szÿmaitis JNŠ 257; 1620 S3ymaitis JNŠ 256. Plg. db. pvd. Šimáitis (LPŽ II 928); * Ta mo ša i t is : 1620 Tamoßaitis JNŠ 251v; 1620 Tamoßaÿtis JNŠ 257v. Plg. db. pvd. Tamošáitis (LPŽ II 1016); *Vai ti e ka it i s : 1601 Waỳtiekajtis JNŠ 20v. Plg. db. pvd. Vaitiekáitis (LPŽ II 
1139); *Venskaitis: 1606 Wenskaitis JNŠ 86v. Plg. db. pvd. Venskáitis (LPŽ II 1190).

-(i)ūnas (rašymas įvairuoja: -(i)un, -(i)unas, -(i)unaf, -(i)unaś, -(i)uns, -unis, -unoś) - 62 (11,15\%) asmenvardžiai: *Andriej ūnas : 1618 Andreiunaf JNŠ 210v. Plg. db. pvd. Andriejúnas (LPŽ I 100); *Baltramiejūnas: 1617 Baltromieiunas JNŠ 198. Plg. db. pvd. Baltramiejūnas (LPŽ I 179); * B a rta ši ūn a s: 1617 Bartoszunis JNŠ 202. Plg. db. pvd. Bartašiúnas (LPŽ I 202); * B artk ūnas : 1601 Bartkuns JNŠ 21. Plg. db. pvd. Bartkúnas (LPŽ I 204); *Griciūnas: 1621 Gricun JNŠ 262v; 1618 Grycun JNŠ 211; 1617 Grýcunoś JNŠ 197v. Plg. db. pvd. Griciúnas (LPŽ I 709); *Grigali ūnas: 1620 Grigalunas JNŠ 256; 1618 Grygalunas JNŠ 210; 1601 Grigaluns JNŠ 19v. Plg. db. pvd. Grigaliúnas (LPŽ I 711); *Jo n k ūn a s: 1621 Iankun JNŠ 267v; 1601 Jonkuns JNŠ 24v. Plg. db. pvd. Jonkúnas (LPŽ I 22); *Jurkūnas: 1601 Jurkunas JNŠ 19; 1601 Jurkuns JNŠ 19. Plg. db. pvd. Jurkúnas (LPŽ I 870); *Krišči ūnas: 1618 Krýsciun JNŠ 211v; 1601 Krifciuns JNŠ 22. Plg. db. pvd. Kriščiúnas (LPŽ I 1081); *Lukoši ūnas: 1601 Lukoßiuns JNŠ 20v; 1620 Lukoßuns JNŠ 251v. Plg. db. pvd. Lukošiúnas (LPŽ II 114); *Maciūnas: 1617 Maciunas JNŠ 197; 1618 Maciunaf JNŠ 216v. Plg. db. pvd. Maciúnas (LPŽ II 125); *Mikalojūnas: 1601 Mikaloiuns JNŠ 20v; 1621 Mikoloiuns JNŠ 267. Plg. db. pvd. Mikalojúnas (LPŽ II 227); *Motiejūnas: 1617 Mateiunaś JNŠ 202v; 1601 Mateiuns JNŠ 20v; 1618 Matieiun JNŠ 211; 1618 mocieiunaf JNŠ 219v; 1617 Moteiunas JNŠ 198; 1617 Moteiunaf JNŠ 208v; 1618 moteiunaf JNŠ 220; 1601 Moteiuns JNŠ 18v. Plg. db. pvd. Motiejúnas (LPŽ II 274); * Pa c i ūn as : 1618 Patfunaf JNŠ 214v. Plg. db. pvd. Paciúnas (LPŽ II 361); *Petroši ūnas: 1601 Petrofiuns JNŠ 21v. Plg. db. pvd. Petrošiúnas (LPŽ II 442); *Stankūnas: 1617 Stankunaś JNŠ 197; 1604 Stankuns JNŠ 48. Plg. db. pvd. Stankúnas (LPŽ II 804); *Sta s i ūnas: 1601 Stafiuna gen. sg. JNŠ 22; 1616 Stasiunas JNŠ 192; 1617 Stasiunas JNŠ 197; 1601 Stafiuns JNŠ 23. Plg. db. pvd. Stasiúnas (LPŽ II 810); * Tamo ši ūn as : 1601 Tamoßiuns JNŠ 23v. Plg. db. pvd. Tamošiúnas (LPŽ II 1016); *Vaitiek ūnas: 1616 Waitiekun JNŠ 191v; 1601 Wajtekuns JNŠ 29v; 1618 Woyciechunaf JNŠ 216; 1617 Wojtechünas JNŠ 197v. Plg. db. pvd. Vaitiekúnas (LPŽ II 1140); *Vait k ū nas: 1601 Waytkuns JNŠ 18; 1617 Woytkunaś JNŠ 199v; 1617 Wojtkunoś JNŠ 208v. Plg. db. pvd. Vaitkúnas (LPŽ II 1141); *Valanči ūnas: 1621 Wałanciun JNŠ 269v. Plg. db. pvd. Valančiúnas (LPŽ II 1146); *Ven sk ūnas: 1601 Węskuns JNŠ 23. Plg. db. pvd. Venskúnas (LPŽ II 1190-1191) bei kt.

-ovič (rašoma: -(i)owicz, -owicz, -owicz) - 59 (10,61 \%) antroponimai: 1618 Bartkowicz JNŠ 214; 1617 Bernatowicz JNŠ 197v; 1620 Czapowicz 
JNŠ 249; 1618 Danilowicz JNŠ 221; 1618 Gregorowicz JNŠ 219; 1618 Gregorzowicz JNŠ 218v; 1618 Grycunowicz JNŠ 211v; 1617 Grygowicz JNŠ 207v; 1621 Iakubowicz JNŠ 249v; 1618 Iakünowicz JNŠ 214; 1618 Iankunowicz JNŠ 212; 1617 Ianowicz JNŠ 197v; 1618 Ianußkowicz JNŠ 214v; 1618 Iekonowicz JNŠ 216v; 1618 Janowicz JNŠ 217v; 1618 Kafperowicz JNŠ 217v; 1620 Laurzinowicz JNŠ 241v; 1618 Macieiowicz JNŠ 210v; 1618 Marcinowicz JNŠ 217v; 1617 Martinowicz JNŠ 199; 1618 Matyiaßowicz JNŠ 222; 1618 Michałowicz JNŠ 209v; 1620 Mikołaiowicz JNŠ 246; 1618 Oftafowicz JNŠ 211v; 1620 Pawłowicz JNŠ 249v; 1618 Piotrowicz JNŠ 214v; 1619 Romanowicz JNŠ 236v; 1601 Stanisławowicz JNŠ 20v; 1618 Staniułowicz JNŠ 210v; 1618 Stasiunowicz JNŠ 216; 1618 Stefanowicz JNŠ 222; 1618 Stephanowicz JNŠ 212v; 1617 Walentynowicz JNŠ 207; 1621 Wawrinowicz JNŠ 262; 1618 Woyciechowicz JNŠ 219v; 1618 Woytkunowicz JNŠ 218v ir kt.

-(i)uitis (rašoma: -(i)uytis, -uitis, -uytis) - 38 (6,83 \%) asmenvardžiai: *Jonuitis: 1618 Ianuytis JNŠ 209. Plg. db. pvd. Jonùitis (LPŽ I 844); *Martynuitis: 1620 Martinuitis JNŠ 243; 1618 Martinuytis JNŠ 214. Plg. db. pvd. Martynuĩtis (LPŽ II 169); *Motiejuitis : 1620 Mateiuytis JNŠ 253. Plg. db. pvd. Motiejuitis (LPŽ II 274) ir kt.

-(i)evič (rašoma: -ewẏz, -(i)ewicz, -iewicz) - 30 (5,42 \%) antroponimų: 1621 Ambrozewicz JNŠ 269v; 1618 Andrzeiewicz JNŠ 212; 1618 Baniewicz JNŠ 217v; 1618 Barthoßewicz JNŠ 213v; 1621 Iendrzeiewicz JNŠ 262; 1621 Iozewicz JNŠ 265v; 1618 Iurgiewicz JNŠ 216v; 1620 Janiskiewicz JNŠ 249v; 1618 Macieiewicz JNŠ 211v; 1618 mikołaiewicz JNŠ 216; 1601 Ostafieiewicz JNŠ 19v; 1621 Paulukiewicz JNŠ 264; 1621 Peczułewicz JNŠ 264; 1601 Thomafzewy்cz JNŠ 21; 1618 więckiewicz JNŠ 215v; 1621 Woicieiewicz JNŠ 270v(2) bei kt.

-onis (rašoma -onis) - 1 (0,18 \%) asmenvardis: *Juknonis: 1617 Iuknonis JNŠ 200. Plg. db. pvd. Juknónis (LPŽ I 853).

Užfiksuoti tik $3(0,54 \%$ visų atkurtų) antroponimų vartojimo atvejai su deminutyvinėmis priesagomis. Kai kada šio tipo priesagos galëjo turèti ir patroniminę reikšmę (dar žr. Zinkevičius 1977a: 241; Maciejauskienė 1991: 227-228; 1993: 43; Ragauskaite 2005: 100-101; 2018a: 105-114; 2019b: 180-190):

-elis (rašoma -(i)elis) - 1 (0,18 \%) asmenvardis: *Mackelis : 1604 Mackielis JNŠ 48. Plg. db. pvd. Mackẽlis (LPŽ II 125);

-(i)ulis (rašoma -(i)ulis) - $1(0,18 \%)$ antroponimas: *Ka s i u li s : 1601 Kasiulis JNŠ 27v. Plg. db. pvd. Kasiùlis (LPŽ I 939);

-utis (rašoma -ütys் $-1(0,18 \%)$ asmenvardis: *Mikutis : 1617 Mikütyś JNŠ 197. Plg. db. pvd. Mikùtis (LPŽ II 236). 
XVI a. pabaigos - XVII a. pradžios Joniškio parapijos gyventojų antroponimų antroje dvinario įvardijimo vietoje dažniausi yra patroniminės kilmės asmenvardžiai. Jų daryba paliudijo lietuviškos patroniminès priesagos -aitis produktyvumą (359, t. y. 65 \%). Tarp XVII a. pradžios vilniečių patronimų, sudarytų su lietuviškomis priesagomis, taip pat dominavo priesagos -aitis vediniai (Zinkevičius 1977a: 56-63). Todèl buvo spejjama, kad visai etnografinei Lietuvai buvo bendra tèvavardžių su priesaga -aitis sistema (Zinkevičius 1977b: 153-155). Tačiau didžiausia priesagos -aitis vedinių koncentracija nustatyta Žemaitijoje ir Vakarų Aukštaitijoje, nors šios priesagos derivatų užrašyta ir įvairiose kitose Lietuvos vietose (Maciejauskienè 1991: 242). Ne tik priesaga -aitis, bet ir kitos lietuvių pavardžių tėvavardinès priesagos -ènas, -onis, -ūnas turi daugiau ar mažiau apibrèžtus priesagu paplitimo arealus Lietuvoje. Antroponimai su priesaga -onis labiausiai paplitę Rytų Lietuvoje ir kai kuriose Pietų Lietuvos vietovėse. Priesagos - ūnas vediniai taip pat dažniausi Rytų Lietuvoje, nors pasitaiko jų ir Pietų Lietuvoje (Maciejauskienė 1977: 161-163; 1991: 242).

Kita asmenvardžiu grupè yra gerokai mažesnè. Ją sudaro tik 4 antroponimai (0,72 \%). Tai: *B a rtku s: 1601 Bartkus JNŠ 21v. Plg. db. pvd. Bar̃tkus (LPŽ I 204); *Jurku s: 1601 Jurkaus gen. sg. JNŠ 21v. Plg. db. pvd. Jur̃kus (LPŽ I 870); *Petrošius: 1604 Petrofius JNŠ 48. Plg. db. pvd. Petrõ̌sius (LPŽ II 442); *Venskus: 1601 Venskaus gen. sg. JNŠ 20. Plg. db. pvd. Veñskus (LPŽ II 1190-1191). Kaip matyti, Joniškio parapijos krikščioniškos kilmès asmenvardžių formos yra labai įvairios.

\section{Antroponimai, nef unkcionuojantys dabartiniame lietuviu vardyne}

XVI a. pabaigos - XVII a. pradžios Joniškio parapijos 146 atkurti krikščioniškos kilmès antroponimai lyginami su dabartinèmis lietuviu pavardèmis. Nesuradus tikslių atitikmenų mūsų dienų vardyne, pateikiami keli būdingesni atitinkamos šaknies asmenvardžiai, pvz.: *And rušk a it is : 1617 Andruszkajtis JNŠ 198. Dèl andrušk- plg. db. pvd. Andruškà, Andruškẽvičius, Andrùškis (LPŽ I 104); *B a l tra mi i jai t is : 1620 Baltromæiaytis JNŠ 259. Dèl baltramiej- plg. db. pvd. Baltramiejúnas (LPŽ I 179); * Baltr uškait is : 1621 Baltrußkaitis JNŠ 266. Dèl baltrušk- plg. db. pvd. Baltruškà, Baltruškẽvičius (LPŽ I 181); *Ba n i u šku it is : 1621 Baniußkuitis JNŠ 265. Dèl baniušk- plg. db. pvd. Baniuškáitis (LPŽ I 188); *B e n i u ša it is : 1601 Beniuszaytis JNŠ 27. Dèl beniuš- plg. db. pvd. Beniušẽvičius, Beniùšis (LPŽ I 233); *Bertaša it is : 1609 Bertaszaitis JNŠ 111v. Dèl bertaš- plg. db. pvd. 
Bertašáuskis, Bertašẽvičius, Bertãšius (LPŽ I 241); *Berta ši ūnas : 1601 Bertafiuns JNŠ 25. Dèl bertaš- plg. db. pvd. Bertašáuskis, Bertašẽvičius, Bertãšius (LPŽ I 241); *Gabruitis: 1601 Gabruitis JNŠ 25. Dèl gabrplg. db. pvd. Gabráitis (LPŽ I 601); *Gasparuitis: 1621 gasparuitis JNŠ 264v. Dèl gaspar- plg. db. pvd. Gasparáitis (LPŽ I 629); *Ge nu la it i s : 1621 Genułaitis JNŠ 260v. Dèl genul- plg. db. pvd. Genùlis (LPŽ I 653); * Gricaitis: 1601 Gricaitis JNŠ 22; 1601 Gricaỳtis JNŠ 29. Dèl gric- plg. db. pvd. Grìcas, Gricẽvičius, Gricỹs, Griciùkas, Griciúnas (LPŽ I 709); *Jaku laiti s: 1601 Jokułaitis JNŠ 26. Dèl jakul- plg. db. pvd. Jakuláuskas, Jakulenis, Jakulẽvičius, Jakùlis (LPŽ I 792); *Ja n k ūna it i s: 1620 Iankunaitis JNŠ 255v. Dèl jankūn- plg. db. pvd. Jankúnas, Jankūnãvičius (LPŽ I 802); *Ja sk a i t i s : 1620 Iaskaitis JNŠ 257. Dèl jask- plg. db. pvd. Jaska, Jaskáuskas, Jaskelis, Jaskẽvičius (LPŽ I 817); *Joci ūnas: 1620 Jaciun JNŠ 249v; 1601 Jocuns JNŠ 18v. Dèl joc- plg. db. pvd. Jocáitis, Jõcas, Jocẽvičius, Jõcius, Jocónis (LPŽ I 835); *Jon uluitis: 1620 Ianułuitis JNŠ 248. Dèl jonul- plg. db. pvd. Jonulaitis (LPŽ I 844); *Jo nu ška it is: 1621 Ianußkaitis JNŠ 261; 1618 Ianußkaytis JNŠ 211v; 1617 Ianu்szkaytiš JNŠ 199; 1620 Ionuscaitis JNŠ 256v; 1616 jonußkaitis JNŠ 192v; 1601 Jonufzkaitis JNŠ 26v. Dèl jonuškplg. db. pvd. Jonuškà, Jonuškẽvičius, Jonùškis (LPŽ I 844); *Ju ka it i s : 1604 Jukaitis JNŠ 48. Dėl juk- plg. db. pvd. Jukãvičius, Jùkelis, Jukénas (LPŽ I 852); *Ju oz u i t is : 1620 Iazuitif JNŠ 249v. Dèl juoz- plg. db. pvd. Juozáitis (LPŽ I 861); *Ju rgu i t i s: JNŠ 201v. Dèl jurg- plg. db. pvd. Jùrgaitis, Jur̃gaitis, Jurgáitis (LPŽ I 866); *Ju rku it is: 1601 Jurkuitis JNŠ 29v. Dèl jurk-plg. db. pvd. Jurkáitis (LPŽ I 868-869); *Krikštanaitis: 1601 Krixtanaytis JNŠ 20. Dèl krikštan- plg. db. pvd. Krikštãnas, Krikštanãvičius (LPŽ I 1076); * Ma cel u i t is : 1620 Macaluitis JNŠ 248. Dèl macel-plg. db. pvd. Mãcelaitis (LPŽ II 122); *Macikait is: 1601 Macikaitis JNŠ 30v. Dèl macik- plg. db. pvd. Macikas (LPŽ II 124); *Ma ciu la it is : 1609 Maciulaitis JNŠ 114. Dèl maciul-plg. db. pvd. Maciulãvičius, Maciulẽvičius, Maciuliónis, Maciùlis (LPŽ II 124-125); *Ma ci u lu i ti s : 1601 Maciuluitis JNŠ 28v. Dèl maciulplg. db. pvd. Maciulãvičius, Maciulẽvičius, Maciuliónis, Maciùlis (LPŽ II 124-125); *Macuitis : 1621 Macuitis JNŠ 262v. Dèl mac- plg. db. pvd. Macáitis (LPŽ II 121); *Mačiuluiti s : 1620 Maczuluitis JNŠ 251v. Dèl mačiul-plg. db. pvd. Màčiulaitis, Mačiuláitis (LPŽ II 129); *Ma s i u l u i t i s : 1621 Masiułuitis JNŠ 264. Dèl masiul- plg. db. pvd. Masiuláitis (LPŽ II 173); *Ma su it is : 1621 Mafuitis JNŠ 263. Dèl mas- plg. db. pvd. Masáitis (LPŽ II 170); *Mika il a i t is: 1601 Mikaiłaỳtis JNŠ 29v; 1601 Mikayłajcia gen. sg. JNŠ 23v. Dèl mikail- plg. db. pvd. Mikáila, Mikáilas, Mikailiónis (LPŽ II 25); *Mi k a il u it is : 1619 Mikaiłuitis JNŠ 236v. Dèl mikail- plg. db. pvd. Mikáila, 
Mikáilas, Mikailiónis (LPŽ II 225); *Mi k it u it is : 1621 Mikituitis JNŠ 269v. Dèl mikit- plg. db. pvd. Mikità, Mikitãvičius (LPŽ II 229); *Mykoluitis : 1617 Mikaluitis JNŠ 205. Dèl mykol- plg. db. pvd. Mykoláitis, Mýkolaitis, Mykolaitis (LPŽ II 231); *Mi ku it is : 1620 Mikuitis JNŠ 248v; 1617 Mikujtis JNŠ 202v. Dèl mik- plg. db. pvd. Mikáitis (LPŽ II 225); *M i ku t u i t i s : 1620 Mikutuitis JNŠ 258. Dèl mikut- plg. db. pvd. Mìkutaitis, Mikutáitis (LPŽ II 236); *Motiekuitis : 1620 Motiekuitis JNŠ 249. Dèl motiek- plg. db. pvd. Motiekà, Motiekáitis, Motiẽkus, Motiekúnas (LPŽ II 274); *Paliuluitis: 1619 Palułuitis JNŠ 232. Dèl paliul- plg. db. pvd. Paliulénas, Paliuliónis, Paliùlis, Paliuliû́nas (LPŽ II 382); *Pa u l u i t is : 1620 Pauluitis JNŠ 248. Dèl paul- plg. db. pvd. Pauláitis (LPŽ II 408); *Peč iu lui tis : 1621 Peczuluitis JNŠ 265v(2). Dèl pečiul- plg. db. pvd. Pèčiulaitis, Pečiuláitis, Pečiulaitis (LPŽ II 420); *Pet ra la it is : 1620 Petrałaitis JNŠ 246v. Dèl petral- plg. db. pvd. Petralẽvičius, Petrãlis (LPŽ II 437); *Petrašaitis: 1618 Pietraßajtis JNŠ 219v. Dèl petraš- plg. db. pvd. Petrašẽvičius, Petrašèuskis, Petrašiúnas, Petrãšius (LPŽ II 438); *Petroši ūnaitis: 1620 Petroßunaitis JNŠ 251v. Dèl petrošiūn- plg. db. pvd. Petrošiúnas (LPŽ II 442); *Pocaitis : 1601 Pocaỳtis JNŠ 28. Dèl poc- plg. db. pvd. Pócas, Pocauskas, Pocẽvičius (LPŽ II 482-483); *Ro ma nu it is : 1619 Romannuýc JNŠ 233. Dèl roman- plg. db. pvd. Romanaitis (LPŽ II 619); *Sta n iu luit is: 1619 Staniułuÿc JNŠ 232; 1618 Staniułuytis JNŠ 211v. Dẻl staniul- plg. db. pvd. Staniuláitis (LPŽ II 802); *Sta nk ūna it is : 1620 Stankunaitis JNŠ 254v. Dèl stankūn- plg. db. pvd. Stankúnas, Stankūnãvičius (LPŽ II 804); *Sto ni ūn as : 1601 Stoniuns JNŠ 18. Dèl ston- plg. db. pvd. Stõnis, Stónis, Stonỹs, Stõnius (LPŽ II 826); *Tamošuitis: 1601 Tamoßuitis JNŠ 30v. Dèl tamoš- plg. db. pvd. Tamošáitis (LPŽ II 1016); *Urnieži u it i s: 1621 Vrnezuitis JNŠ 259v. Dèl urniež- plg. db. pvd. Urniẽžis, Urniẽžius (LPŽ II 1113); *Vaitiekuitis : 1619 Vaitekuitif JNŠ 237. Dèl vaitiek- plg. db. pvd. Vaitiekáitis (LPŽ II 1139); *Val a nča it i s : 1617 Wolączaỳtis JNŠ 202. Dèl valanč- plg. db. pvd. Valančáuskas, Valančiónis, Valančis, Valančiúnas, Valañčius (LPŽ II 1146); *Valentinaitis: 1601 Valentinaitis JNŠ 19v. Dèl valentin- plg. db. pvd. Valentinas, Valentinãvičius (LPŽ II 1150); *Va siula it is: 1601 Wasiułaitis JNŠ 28. Dèl vasiul- plg. Vasiuliauskas, Vasiùlis (LPŽ II 1170).

Paaiškèjo, kad 92 (63 \% visu rekonstruotų) atkurti asmenvardžiai vartojami ir šiomis dienomis. Dalis, t. y. 54 (37 \%) turi tos pačios kilmès, tik skirtingos darybos dabartinių pavardžių atitikmenis. Tarp šiuo metu nepaliudytų antroponimų dažni priesagos -(i)uitis vediniai. Ankstesni XVII a. lietuvių istorinių asmenvardžiu tyrimai beveik nėra paliudiję šios priesagos vartosenos. Tačiau manoma, kad priesaga -uitis yra vadintina patronimine priesaga. Tai 
leidžia daryti XVII a. Gruzdžių parapijos antroponimų su priesaga -uitis gausa ir detali jų antroponiminè analizė (Maciejauskienė 2010: 820). Tarp nagrinètų XVI-XVII a. Joniškio miestiečių patroniminès kilmės asmenvardžių priesagos -(i)uitis vediniai sudare 14,60 \% (Ragauskaitė 2019b: 187, 194). Kai kurie straipsnyje analizuoti krikščioniškos kilmès antroponimai yra vertintini kaip grafiniai variantai. Jie galèjo atsirasti nedėsningai dẻl raštininkų neatidumo ar kt. ekstralingvistinių aplinkybių (lietuvių, lenkų ir lotynų kalbų sąveikos).

\section{Išvados}

1. Iš 1599-1621 m. Joniškio parapijos krikšto metrikų knygos buvo atrinkti kaimų gyventojų 556 dvinariai užrašymai. Pirmieji šių dvinarių ịvardijimų nariai - tai krikščioniški vardai. Daugiausia surasta tradicinių krikščioniškų vardų lyčių.

2. Darybinei analizei atrinkti 556 krikščioniškos kilmès asmenvardžiai (antrieji dvinario įvardijimo modelio nariai) buvo suskirstyti ị dvi grupes: 1) antroponimai su lietuviškomis -aitis, -(i)onis, -(i)ūnas, -(i)uitis ir slaviškomis -evič, -ovič patroniminėmis priesagomis, su deminutyvinèmis priesagomis ir 2) asmenvardžiai be šiu priesagų.

3. Pirmoji grupè yra gerokai didesnè. Ją sudaro 552 (99,28\% visų antrųju antroponimų) asmenvardžiai. Tarp jų dažniausi patroniminių priesagų -aitis (359, t. y. $65 \%$ ) vediniai. Antrojoje grupejje tik 4 (0,72\%) antroponimai.

4. Palyginus 146 atkurtų asmenvardžių formas su dabartinėmis lietuvių pavardèmis, nustatyta, kad 92 (63\%) funkcionuoja ir šiandien. Mažesnè dalis, t. y. 54 (37 \% visų atkurtų antroponimų) turi tos pačios kilmès, tik skirtingos darybos dabartinių pavardžių atitikmenis. 


\section{Priedai}

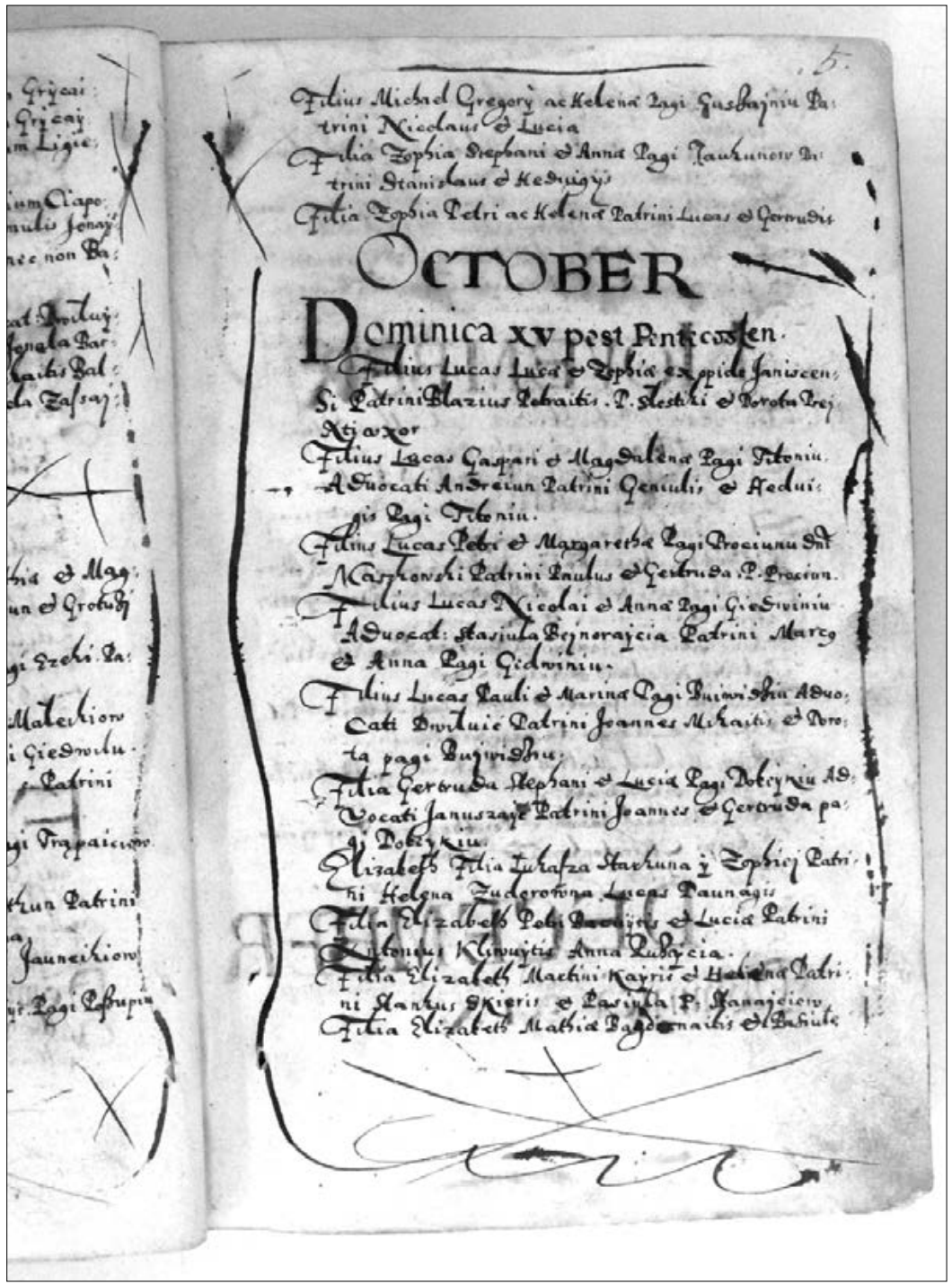

1 pav. $1599 \mathrm{~m}$. fragmentas iš $1599-1621 \mathrm{~m}$. Joniškio parapijos

krikšto metrikų knygos (1. 5) 


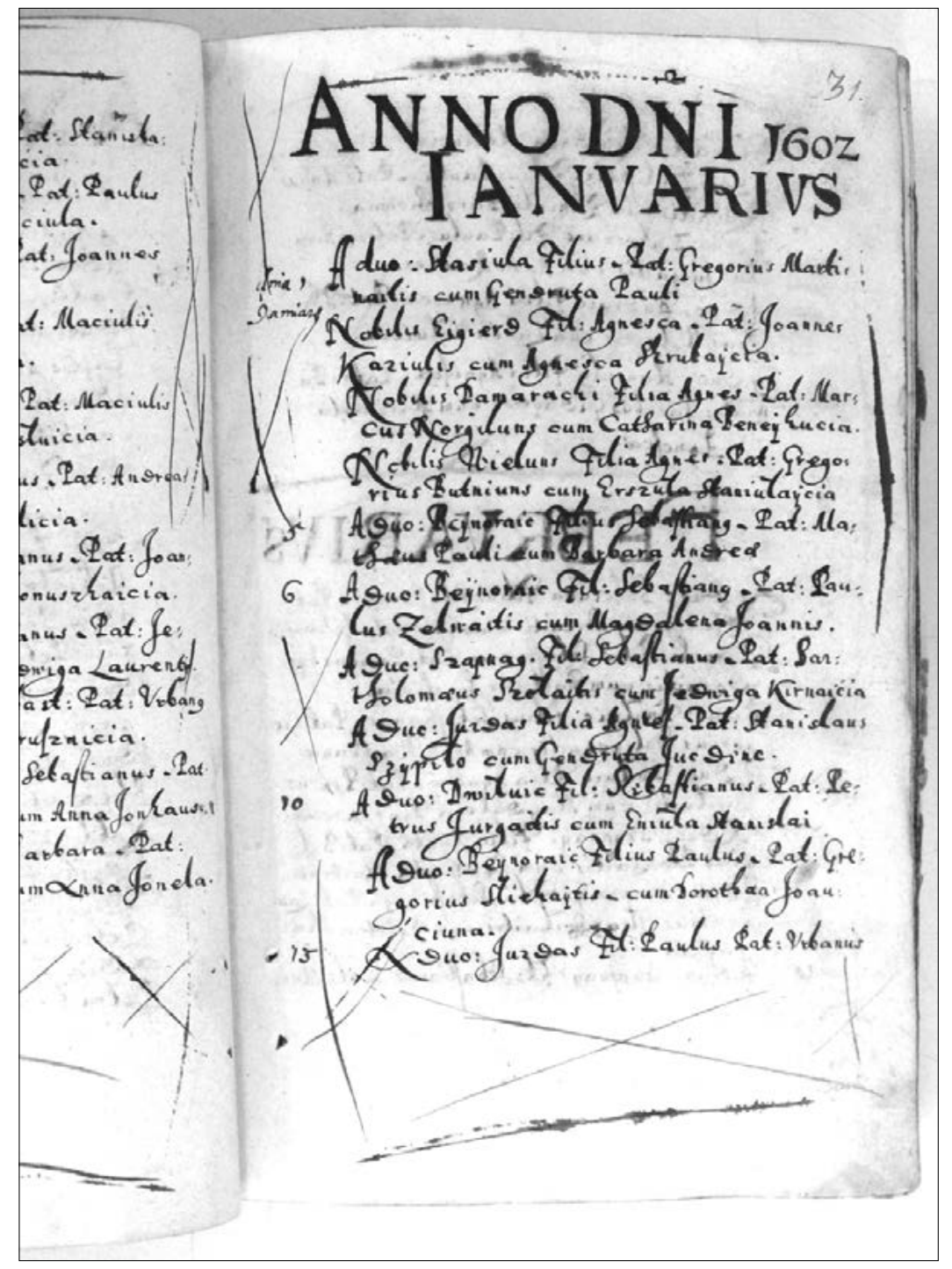

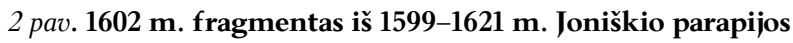
krikšto metrikų knygos (1. 31) 


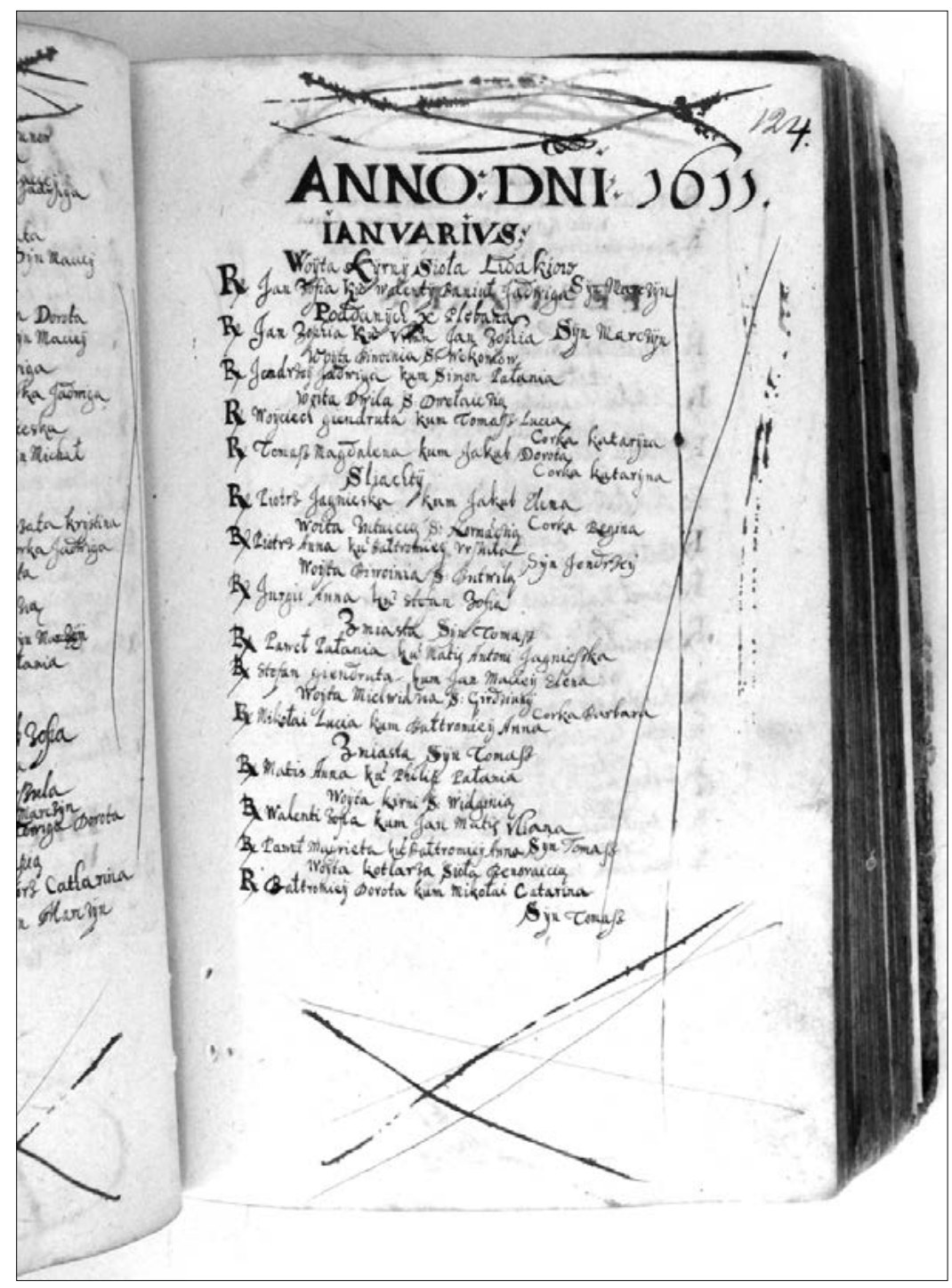

3 pav. $1611 \mathrm{~m}$. fragmentas iš $1599-1621 \mathrm{~m}$. Joniškio parapijos krikšto metrikų knygos (1. 124) 


\section{Sutrumpinimai}

db. - dabartinis, $-\dot{e}$

gen. - lo. (cāsus) genetīvus 'kilmininko linksnis'

plg. - palygink

sg. - lo. (numerus) singulāris 'vienaskaita'

pvd. - pavardè

v. - vardas

\section{Istorijos šaltinis}

Jnš = 1599-1621 m. Joniškio parapijos krikšto metrikų knyga [„Liber Baptisatoru(m) \| Ecc(lesi)æ Parochialis Jani=\|scensis ab Anno 1599. - \| usq(ue) ad An(n)um || 1621. -"]. Lietuvos valstybès istorijos archyvas. F. 1196. Ap. 1. B. 76.

\section{Literatūra}

Garliauskas, Vidas. 1998. Lietuviškos oikonimų lytys nelietuviškuose XVI-XIX a. šaltiniuose. Lietuvių kalbotyros klausimai 40, 123-204.

Garliauskas, Vidas. 2004. XVII a. Molètų bažnyčios krikšto ir santuokos metrikų knyga.

LPŽ I-II =

LVKŽ =

Maciejauskienè, Vitalija. 1977.

Maciejauskienè, Vitalija. 1991.

Maciejauskienè, Vitalija. 1993.

Maciejauskienè, Vitalija. 2010.

Ragauskaitè, Alma. 1999.

Ragauskaité, Alma. 2004.

Ragauskaitè, Alma. 2005.

Ragauskaite, Alma. 2015.

Ragauskaite, Alma. 2018a. Vilnius: Mokslo ir enciklopediju leidybos institutas.

Lietuviu pavardžiu žodynas 1-2, aut. Vitalija Maciejauskienė, Marija Razmukaite, Aleksandras Vanagas, ats. red. Aleksandras Vanagas. Vilnius: Mokslas, 1985-1989.

Lietuviu vardu kilmés žodynas, aut. Kazys Kuzavinis, Bronys Savukynas. Vilnius: Mokslo ir enciklopedijų leidykla, 1994.

Lietuvių asmenvardžių priesagų paplitimas XVII a. Lietuvių kalbotyros klausimai 17, 159-168.

Lietuvių pavardžių susidarymas XIII-XVIII a. Vilnius: Mokslas.

Kriaunų parapijos XVII-XVIII a. asmenvardžiai. Lietuviu kalbotyros klausimai, 32: Baltu onomastikos tyrimai, 34-99.

Gruzdžių pavardès: istorija ir dabartis. Gruzdžiai 2, Vilnius: Versmè, 818-844.

XVI a. II pusès Kauno miestiečiu lietuviškos kilmès asmenvardžiai. Acta Linguistica Lithuanica / Lietuvių kalbotyros klausimai 41, 145-158.

XVI-XVII a. joniškiečių asmenvardžiai. Istoriniai tekstai ir vietos kultūra. Šiauliai, Ryga: Lucilijus, 8-18.

XVI-XVIII a. kauniečių asmenvardžiai. Vilnius: Lietuvių kalbos instituto leidykla.

Seniausios Lietuvoje 1599-1621 metų Joniškio krikšto metrikų knygos joniškiečių moterų asmenvardžiai lietuvių istorinès antroponimijos kontekste. Acta Linguistica Lithuanica 73, 55-81.

XVII a. kèdainiečiu asmenvardžių darybos tendencijos. Baltu filologiija 27, 101-118. 
Ragauskaitè, Alma. 2018b. XVII a. kèdainiečių lietuviškos kilmès asmenvardžiai. Acta Linguistica Lithuanica 78, 53-75.

Ragauskaitè, Alma. 2019a. Lietuviškos kilmès asmenvardžiai seniausioje Lietuvoje 15991621 m. Joniškio krikšto metrikų knygoje. Baltu filologija 28(1), 153-168.

Ragauskaitè, Alma. 2019b. Joniškiečių vyrų asmenvardžių darybos tendencijos seniausioje Lietuvoje 1599-1621 m. Joniškio krikšto metrikų knygoje. Acta Linguistica Lithuanica 80, 177-194.

Vanagas, Aleksandras. 1974. Pavardès iš hebrajiškos kilmès vardų. Žodžiai ir žmonès. Vilnius: Mintis, 86-152.

Vanagas, Aleksandras. 1977. Pavardès iš graikiškos kilmès vardų. Žmonès ir kalba. Vilnius: Mokslas, 48-92.

Vanagas, Aleksandras. 1980. Pavardès iš lotyniškos kilmès vardų. Kalba ir mintis. Vilnius: Mokslas, 52-95.

Vanagas, Aleksandras. 1982. Mūsų vardai ir pavardès. Vilnius: Mokslas, 68-72.

Vanagas, Aleksandras. 1983. Pavardès iš slaviškos kilmès vardų. Mintis ir ženklas. Vilnius: Mokslas, 73-103.

Zinkevičius, Zigmas. 1977a. Lietuvių antroponimika. Vilniaus lietuvių asmenvardžiai XVII a. pradžioje. Vilnius: Mokslas.

Zinkevičius, Zigmas. 1977b. Tẻvavardinè asmenvardžių sistema Lietuvoje. Baltistica. II priedas, 151-156.

Zinkevičius, Zigmas. 2005. Krikščionybès ištakos Lietuvoje. Vilnius: Katalikų akademija.

Zinkevičius, Zigmas. 2007. Senosios Lietuvos valstybès vardynas. Vilnius: Mokslo ir enciklopedijų leidybos institutas.

Zinkevičius, Zigmas. 2008. Lietuvių asmenvardžiai. Vilnius: Lietuvių kalbos institutas.

Zinkevičius, Zigmas. 2010. Krikščioniško vardyno kelione i Lietuvą. Vilnius: Lietuvių kalbos instituto leidykla.

Žilys, Saulius. 2012. Bažnyčių metrikų knygos ir parapijiečių sąrašai Lietuvos mokslų akademijos Vrublevskių bibliotekos Rankraščiu skyriuje: kilmè ir konfesiniai ypatumai. Atminties instituciju rinkiniai. Bibliotheca Lithuana 2. Vilnius: Vilniaus universiteto leidykla, 123-154.

\author{
Alma Ragauskaite \\ Baltu kalbu ir vardyno tyrimu centras \\ Lietuviu kalbos institutas \\ P. Vileišio g. 5, LT-10308 Vilnius, Lietuva \\ alma.ragauskaite@lki.lt \\ ORCID: 0000-0001-5952-8027
}




\title{
KOPSAVILKUMS
}

\section{Kristīgas cilmes personvārdi vecākajā lietuviešu kristību metriku grāmatā Jonišḳos (1599-1621)}

\begin{abstract}
Alma RAGAUSKAITÉ
Draudžu metriku grāmatas ir viens no svarīgākajiem Lietuvas vēsturiskās antroponīmijas izpētes avotiem. Šo reğistru kontekstā izceḷas hronolog̣iski unikāls Jonišksu pilsētas kristību reg̣istrs no 1599. līdz 1621. gadam, kas pašlaik ir vecākais zināmais lietuviešu draudzes reǵistrs Lietuvā. No 556 kristīgas cilmes antroponīmiem, kas analizēti rakstā, 146 gadījumos tika rekonstruētas personvārdu formas (*Andriejūnas, *Baltramiejūnas, *Čepaitis, *Griciūnas, *Jankūnas, *Kasiulis, *Laurynaitis, *Motiejuitis, *Petraitis, *Ramonaitis, *Stanaitis, *Šimaitis, *Tamošaitis, *Vaitiekaitis). Salīdzinot rekonstruētos antroponīmus un mūsdienu Lietuvas uzvārdus, redzams, ka 92 (63 \%) no tiem mūsdienās ir joprojām sastopami. Daḷai no tiem, t. i. 54 (37 \% no visiem rekonstruētajiem antroponīmiem), ir atrodami līdzīgi tās pašas cilmes uzvārdi, taču ar atšksirīgiem formantiem ( ${ }^{*}$ Andruškaitis, ${ }^{*}$ Baniuškuitis, ${ }^{*}$ Gricaitis, ${ }^{*}$ Maciuluitis, *Pečiuluitis, *Romanuitis, ${ }^{*}$ Stankūnaitis, ${ }^{*}$ Tamošuitis, ${ }^{*}$ Urniežiuitis, ${ }^{*}$ Valančaitis).
\end{abstract}

\section{SUMMARY}

\section{Personal Names of Christian Origin in the Oldest Lithuanian Baptismal Register of Joniškis Parish (1599-1621)}

\section{Alma RAGAUSKAITÉ}

Parish registers are among the most important historical documents of Lithuanian historical anthroponymy. A chronologically unique baptismal register of Joniškis parish dating from 1599-1621, which is currently the oldest known Lithuanian parish register in Lithuania, stands out in the context of such registers. Out of 556 anthroponyms of Christian origin analysed in the article, 146 personal names with Lithuanian suffixes were reconstructed (*Andriejūnas, *Baltramiejūnas, *Čepaitis, *Griciūnas, *Jankūnas, *Kasiulis, *Laurynaitis, *Motiejuitis, *Petraitis, *Ramonaitis, ${ }^{*}$ Stanaitis, ${ }^{*}$ Šmaitis, ${ }^{*}$ Tamošaitis, ${ }^{*}$ Vaitiekaitis). A comparison of the reconstructed anthroponyms and present-day Lithuanian surnames shows that $92(63 \%)$ of them still occur today. Some of them, i. e. 54 (37\% of all reconstructed anthroponyms), have equivalent surnames of the same origin but different formation ( ${ }^{*}$ Andruškaitis, ${ }^{*}$ Baniuškuitis, ${ }^{*}$ Gricaitis, *Maciuluitis, ${ }^{*}$ Pečiuluitis, ${ }^{*}$ Romanuitis, ${ }^{*}$ Stankūnaitis, ${ }^{*}$ Tamošuitis, ${ }^{*}$ Urniežiuitis, ${ }^{*}$ Valančaitis). 